\title{
ALS-Resistant Spotted Spurge (Chamaesyce maculata) Confirmed in Georgia
}

\author{
Patrick E. McCullough, J. Scott McElroy, Jialin Yu, Hui Zhang, Tyler B. Miller, Shu Chen, \\ Christopher R. Johnston, and Mark A. Czarnota*
}

Metsulfuron is used for POST control of spotted spurge in many warm-season turfgrasses. A suspected resistant $(\mathrm{R})$ biotype of spotted spurge was collected from turfgrass in Georgia with a history of exclusive metsulfuron use. Research was conducted to evaluate the resistance level of this biotype to metsulfuron, efficacy of other mechanisms of action for control, and the molecular basis for resistance. Compared with a susceptible (S) biotype, the R biotype required $>90$ and $>135$ times greater metsulfuron rates to reach $50 \%$ injury and reduce biomass $50 \%$ from the nontreated, respectively. The $\mathrm{R}$ biotype was also resistant to trifloxysulfuron but was injured equivalent to the $S$ biotype from dicamba, glyphosate, and triclopyr. Gene sequencing of the $\mathrm{R}$ biotype revealed a $\operatorname{Trp}_{574}$ to Leu substitution that has conferred resistance to acetolactate synthase (ALS) inhibitors in previous research. This is the first report of ALS resistance in spotted spurge. More importantly, this is the first report of a herbicide-resistant broadleaf weed from a turfgrass system in the United States.

Nomenclature: Metsulfuron-methyl; spotted spurge, Chamaesyce maculata (L.) Small.

Key words: Efficacy, mutation, sulfonylurea, turfgrass.

Spotted spurge is an annual weed in row crops, nurseries, and turfgrass systems (Bararpour et al. 1994; Cross and Skroch 1992; Dunn 1979). Plants have pubescent leaves on branching stems with prostrate or decumbent growth habits (Elmore and McDaniel 1986). Spotted spurge produces thousands of seed that contributes to infestations and reductions in crop yield (Dunn 1979; Elmore and McDaniel 1986; Krochmal 1952). In turfgrass, mechanical control is often ineffective because of regrowth of shoots after mowing. Hand weeding spotted spurge is ineffective if the entire plant is not completely removed from the soil. PRE herbicides, such as dithiopyr and isoxaben, control spotted spurge in container-grown perennials and ornamental grasses (Derr 1994, 2002; Judge et al. 2004; Norcini and Aldrich 1992). However, initial seed germination begins at $25 \mathrm{C}$, which is later than most summer annual weeds of turf (Asgarpour et al. 2015; Hope 1982). PRE herbicides applied in early spring may have erratic efficacy for controlling spotted spurge that could warrant POST herbicide use.

DOI: 10.1614/WS-D-15-00142.1

* First, third, and seventh authors: Associate Professor, Postdoctoral Researcher, and Graduate Research Assistant, Department of Crop and Soil Science, University of Georgia, Griffin, GA 30223; second, fourth, fifth, and sixth authors: Professor, Graduate Research Assistant, Undergraduate Student, and former Graduate Research Assistant, Department of Crop, Soil, and Environmental Sciences, Auburn University, Auburn, AL 36849; eighth author: Associate Professor, Horticulture Department, University of Georgia, Griffin, GA 30223. Corresponding author's E-mail: pmccull@uga.edu
Metsulfuron-methyl (metsulfuron) is an acetolactate synthase (ALS) inhibitor that provides POST control of spurge species (Chamaesyce spp.) in tolerant turfgrasses (Derr 2012; McCarty 1991). Practitioners use metsulfuron in the southern United States because of economics and the tolerance of major warm-season turfgrasses to labeled use rates (Anonymous 2015). Resistance to ALS inhibitors has increased exponentially over the last decade in turf and other cropping systems (Heap 2015). Weed biotypes with resistance to ALS inhibitors have altered target site enzymes or enhanced metabolism (Tranel and Wright 2002). In turfgrass, target site alteration has conferred resistance to ALS inhibitors in annual bluegrass (Poa annua L.) and annual sedge (Cyperus compressus L.) populations and is more common than metabolism-based resistance (Cross et al. 2013; McCullough et al. 2016; McElroy et al. 2013; Shaner 1999; Whaley et al. 2006; Zheng et al. 2011). The spread of resistant ( $R$ ) biotypes may be exacerbated by pollen-mediated gene flow of nuclear alleles that transfer resistance to susceptible populations, along with selection pressure from herbicide use (Powles and Yu 2010; Yu and Powles 2014; Yu et al. 2008).

A spotted spurge biotype with suspected resistance to metsulfuron was identified in a seashore paspalum (Paspalum vaginatum Sw.) field in Georgia. The manager used metsulfuron exclusively for about two decades, but reductions in control were noted in 2010 . Spotted spurge biotypes with ALS resistance could create considerable problems for POST control in many turfgrass species that are susceptible to injury from alternative herbicides. The objectives of this research were to evaluate (1) the resistance level of 
Table 1. Injury of two spotted spurge biotypes at $4 \mathrm{wk}$ after treatments with six herbicides in two greenhouse experiments at Griffin, GA. Results were pooled over experimental runs.

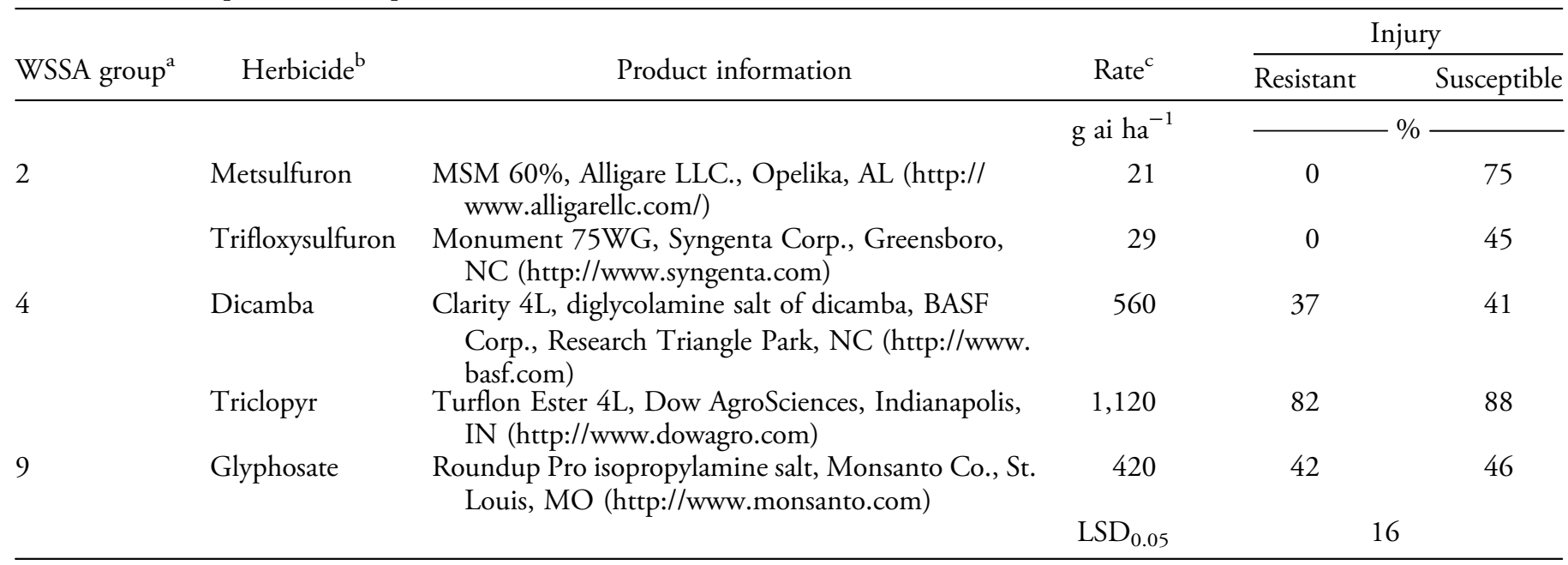

\footnotetext{
${ }^{a}$ Weed Science Society of America (WSSA) group numbers listed represent (2) acetolactate synthase inhibitors, (4) synthetic auxins, and (9) EPSP synthase inhibitor.

${ }^{\mathrm{b}}$ Metsulfuron and trifloxysulfuron were applied with a nonionic surfactant at $0.25 \% \mathrm{vol} / \mathrm{vol}$ except glyphosate. The surfactant used was Chem Nut 80-20, mixture of alkyl and arlkylaryl polyoxyethylene glycol, 80\%, Chem Nut Inc., P.O. Box 3706 , Albany, GA 31706.

${ }^{\mathrm{c}}$ Dicamba and glyphosate rates are $\mathrm{g}$ ae $\mathrm{ha}^{-1}$.
}

this biotype to metsulfuron, (2) efficacy of other mechanisms of action for POST control, and (3) the molecular basis for resistance.

\section{Materials and Methods}

Plant Material. Spotted spurge plants were collected from a 'Sea Isle 1' seashore paspalum field in Cook County, GA. The location coordinates will not be disclosed to protect the privacy of the landowner. A 27$\mathrm{m}^{2}$ area was sprayed on July 1, 2014, with metsulfuron (Manor 60WG, Nufarm Americas, Burr Ridge, IL) at $84 \mathrm{~g}$ ai ha ${ }^{-1}$, which is eight times the standard use rate. Plants that were not controlled from this treatment were removed from the field by hand on August 12, 2014. Spotted spurge was also collected in Griffin, GA, from a susceptible (S) population. The two biotypes were then transplanted to separate plastic pots of $79-\mathrm{cm}^{2}$ surface areas and $10-\mathrm{cm}$ depths and filled $80: 20(\mathrm{v} / \mathrm{v})$ sand : peat moss. Pots were placed in a greenhouse set at 32/25 $\mathrm{C}$ day/night temperatures at the University of Georgia Griffin Campus. Approximately 20 plants of each biotype were irrigated as needed to prevent moisture deficiencies. Seeds were planted immediately after collection by hand and scattered over pots of $3.8-\mathrm{cm}$ diam and $20-\mathrm{cm}$ depth with the aforementioned potting medium. Pots were fertigated (MacroN 28-7-14 sprayable fertilizer, LESCO Inc., Cleveland, $\mathrm{OH}$ ) weekly and allowed to produce three to five branches before treatments. Pots were thinned to single plants before treatments were applied.
Metsulfuron Dose-Response Experiments. The resistance level of the $\mathrm{R}$ biotype was compared with the $S$ biotype in a rate titration of metsulfuron. Treatments were applied in a spray chamber calibrated to deliver $187 \mathrm{~L} \mathrm{ha}^{-1}$ with a flat fan nozzle (8002E, TeeJet Spraying Systems Co., Roswell, GA). Metsulfuron-methyl (60\%, Alligare LLC, Opelika, AL) was applied at 1.3, 2.6, 5.3, 10.5, 21, 42, 84,168 , or $336 \mathrm{~g} \mathrm{ha}^{-1}$. This range was chosen based on standard use rates for spurge control in turfgrass (10.5 to $21 \mathrm{~g} \mathrm{ha}^{-1}$ ). Nontreated checks of the two biotypes were included. A nonionic surfactant (Chem Nut 80-20, mixture of alkyl and alkylaryl polyoxyethylene glycol, 80\%, Chem Nut Inc., Albany, GA) was added to the spray solution at $0.25 \%(\mathrm{v} / \mathrm{v})$. Plants were returned to the greenhouse at $\sim 1 \mathrm{~h}$ after treatment and did not receive irrigation until $24 \mathrm{~h}$ after treatment. Injury was visually evaluated at $4 \mathrm{wk}$ after treatment (WAT) on a scale of 0 (no injury) to $100 \%$ (complete desiccation). Shoot biomass was harvested 4 WAT, oven-dried for $72 \mathrm{~h}$ at $60 \mathrm{C}$, and then weighed.

Multiple and Cross-Resistance Experiment. In another experiment, the two biotypes were treated with dicamba, glyphosate, metsulfuron, triclopyr, or trifloxysulfuron. A nontreated check was included. Application rates and product information are presented in Table 1. Metsulfuron and trifloxysulfuron were applied with the aforementioned surfactant. Injury was visually evaluated 4 WAT as previously described. 


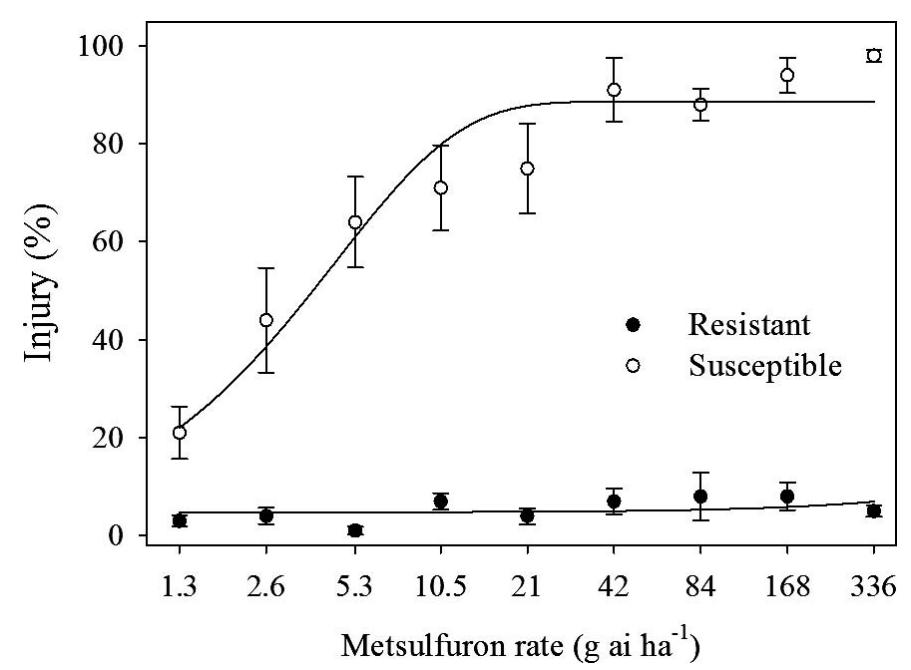

Figure 1. Injury of two spotted spurge biotypes after treatment with metsulfuron in two greenhouse experiments in Griffin, GA. Results were pooled over two experimental runs. Vertical bars represent standard errors of the mean $(n=8)$. Data for the susceptible $(\mathrm{S})$ biotype was regressed with the following equation: $y=\beta_{0}\left\{1-\left[\exp \left(-\beta_{1} x\right)\right]\right\}$, where $y$ is injury, $\beta_{0}$ is the asymptote, and $\beta_{1}$ is the slope estimate. Data for the resistant $(\mathrm{R})$ biotype was regressed with the following equation: $y=\beta_{0}+\beta_{1} x$, where $\beta_{0}$ and $\beta_{1}$ are the intercept and slope, respectively. Regression for the $S$ biotype: $y=87.68\{1-[\exp (-0.23 x)]\}$. Standard errors for $\beta_{0}$ and $\beta_{1}$ measured 3.3 and 0.04 , respectively. The $95 \%$ confidence intervals for $\beta_{0}$ and $\beta_{1}$ measured $81-94$ and $0.14-0.31$, respectively. Regression for the $\mathrm{R}$ biotype is $4.56+0.002 x$. The standard error for the intercept and slope measured 0.9 and 0.007 , respectively. The $\mathrm{I}_{50}$ for the $\mathrm{R}$ and $\mathrm{S}$ biotypes measured $>336 \mathrm{~g} \mathrm{ha}^{-1}$ and $3.7 \mathrm{~g} \mathrm{ha}^{-1}$, respectively. The $95 \%$ confidence interval for the $\mathrm{I}_{50}$ estimate for the $\mathrm{S}$ biotype is 2.6-4.9.

The design for greenhouse experiments was a randomized complete block with four replications. A block design was chosen to minimize potential variability in greenhouse location on plant responses to treatments. Both experiments were repeated once. Data were subjected to ANOVA with PROC GLM in SAS (SAS v. 9.3, Cary, NC). For plant injury, data were plotted and regressed with an exponential growth function and linear equation to describe the relationship of herbicide rate with plant responses,

$$
\begin{aligned}
& y=\beta_{0}\left\{1-\left[\exp \left(-\beta_{1} x\right)\right]\right\} \\
& y=\beta_{0}+\beta_{1} x
\end{aligned}
$$

where $y$ is injury, $\beta_{0}$ is the asymptote (Equation 1 ) or intercept (Equation 2), $\beta_{1}$ is the slope estimate, and $x$ is metsulfuron rate (Figure 1). For shoot biomass, data were regressed with the following threeparameter growth function model,

$$
y=\beta_{0}+\beta_{1} \exp \left(-\beta_{2} x\right),
$$

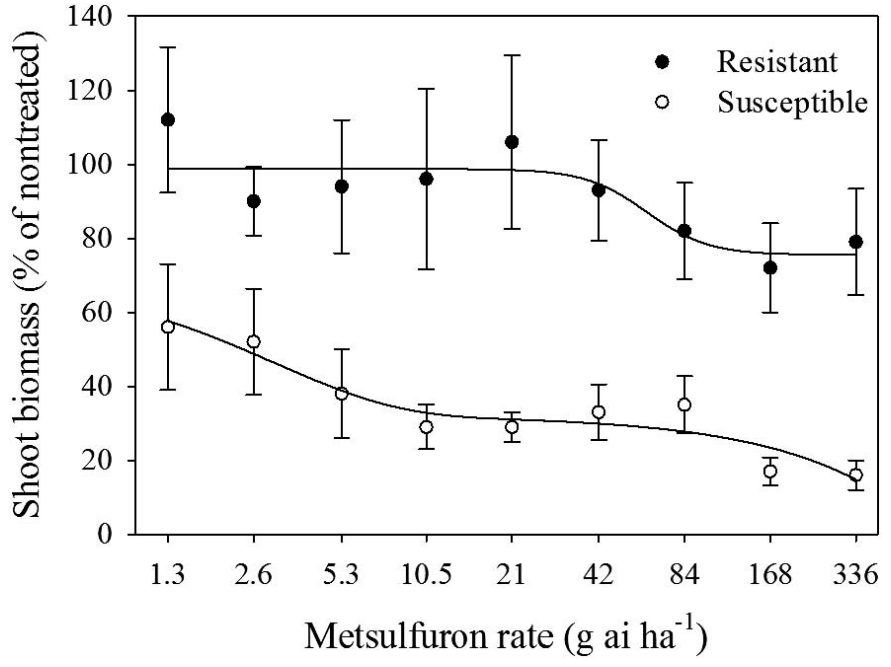

Figure 2. Dry shoot biomass of two spotted spurge biotypes at 4 wk after treatment with metsulfuron in two greenhouse experiments in Griffin, GA. Results were pooled over experimental runs. Vertical bars represent standard errors of the mean $(n=8)$. Biomass for the nontreated averaged 0.23 ( \pm 0.02 SEM) and 0.15 ( \pm 0.02 SEM) $\mathrm{g}$ plant $^{-1}$ for the $R$ and $S$ biotypes, respectively. Data were regressed with the following equation: $y=\beta_{0}+\beta_{1}\left[\exp \left(-\beta_{2} x\right)\right]$, where $y$ is shoot biomass, $\beta_{0}$ is the lower asymptote, $\beta_{1}$ is the maximum predicted response, $\beta_{2}$ is the slope, and $x$ is metsulfuron rate. Regression for the $\mathrm{R}$ biotype: $73.63+$ $25.29[\exp (-0.011 x)]$. Standard errors for $\beta_{0}, \beta_{1}$, and $\beta_{2}$ measured 22.3, 21.8, and 0.03, respectively. The $95 \%$ confidence intervals for $\beta_{0}, \beta_{1}$, and $\beta_{2}$ measured $29-118,-18$ to 69 , and -0.04 to 0.06 , respectively. Regression for the susceptible biotype: $24.91+42.21[\exp (-0.21 x)]$. Standard errors for $\beta_{0}$, $\beta_{1}$, and $\beta_{2}$ measured $4.2,16.9$, and 0.16 , respectively. The $95 \%$ confidence intervals for $\beta_{0}, \beta_{1}$, and $\beta_{2}$ measured 16-33, 9-76, and -0.1 to 0.5 , respectively. The $\mathrm{GR}_{50}$ for the $\mathrm{R}$ and $\mathrm{S}$ biotypes are $>336$ and $2.5 \mathrm{~g} \mathrm{ha}^{-1}$, respectively. The $95 \%$ confidence interval for the $\mathrm{GR}_{50}$ of the $\mathrm{S}$ biotype is $<1.3-7$.

where $y$ is shoot biomass, $\beta_{0}$ is the lower asymptote, $\beta_{1}$ is the maximum predicted response, $\beta_{2}$ is the slope, and $x$ is metsulfuron rate (Figure 2). Metsulfuron rates that caused $50 \%$ injury $\left(\mathrm{I}_{50}\right)$ and $50 \%$ reductions in shoot mass $\left(\mathrm{GR}_{50}\right)$ from the nontreated were calculated to facilitate discussion of the results. The $95 \%$ confidence limit for $\mathrm{I}_{50}$ and $\mathrm{GR}_{50}$ values were calculated in SigmaPlot (v. 11.2, Systat Software Inc., San Jose, CA) with the aforementioned regression analyses. For the evaluation of various herbicides, means were separated with Fisher's LSD test at $\alpha=0.05$. Treatment-by-experimental run interactions were not detected; therefore, results were pooled over runs for presentation.

ALS Gene Assembly, Mapping, and SNP Detection. Plants used for gene sequencing were collected from the populations that were seeded for the aforementioned experiments. To identify potential target site mutations, massively parallel 
sequencing using the Illumina HiSeq (Illumina, San Diego, CA; http://www.illumina.com/) platform was utilized in lieu of traditional short-read capillary sequencing using polymerase chain reaction. Methodologies for the assembly and polymorphism detection in a nonmodel organism with no reference genome or transcriptome were based on suggestions by Brautigam and Gowik (2010). RNA was extracted using a standard RNA extraction kit (RNeasy Plant Mini Kit, Qiagen, Venlo, The Netherlands; http://www.qiagen.com). Illumina sequencing, including all RNA preparation steps before sequencing, was conducted at the Hudson Alpha Institute for Biotechnology (Huntsville, AL, USA; http://gsl.hudsonalpha.org/).

Sequencing reads were processed using the Trinity de novo assembly pipeline (http://trinityrnaseq. sourceforge.net/) (Grabherr et al. 2011; Haas et al. 2013). Reads of the two biotypes were separately paired, trimmed, and de novo assembled using Trinity RNA-Seq de novo assembler. Contiguous assembled sequences (contigs) identified as ALSexpressed genes were identified using a local BLAST search. To facilitate the BLAST search, full-length ALS protein sequences were downloaded from the National Center for Biotechnology Information (NCBI; http://www.ncbi.nlm.nih.gov/). Local BLAST was conducted using tblastn within CLC Genomics Workbench (CLC Bio, Primset, Denmark; http:// www.clcbio.com/). The assemblies of the two biotypes were converted to BLAST databases, and NCBI protein sequences were searched against the assembly databases. Contigs were identified and extracted from each assembly as similar to ALS proteins. Extracted putative ALS contigs were aligned and compared using alignment within CLC Genomics Workbench. The ALS sequences of two biotypes were submitted to NCBI (GenBank KT382543 and KT382544 for R and $\mathrm{S}$ biotypes, respectively).

\section{Results and Discussion}

Metsulfuron Dose-Response Experiments. A biotype-by-rate interaction was detected for injury; thus, results are presented by biotype. The metsulfuron rate that injured the $S$ and R biotypes $50 \%$ measured 3.7 and $>336 \mathrm{~g} \mathrm{ha}^{-1}$, respectively (Figure 1). The $\mathrm{R}$ biotype was injured $<8 \%$ from all application rates, but $\geq 42 \mathrm{~g} \mathrm{ha}^{-1}$ injured the $\mathrm{S}$ biotype $>87 \%$. Similarly, a metsulfuron rate that reduced biomass of the $\mathrm{S}$ and $\mathrm{R}$ biotypes by $50 \%$ from the nontreated measured 2.5 and $>336 \mathrm{~g} \mathrm{ha}^{-1}$, respectively (Figure 2).
The resistance factor for this spotted spurge biotype is $>90$-fold greater than the $S$ biotype. Trezzi et al. (2005) reported that wild poinsettia (Euphorbia heterophylla L.) from Brazil had >24-fold resistance to imazethapyr than an $S$ biotype. It was also determined that the biotype was resistant to metsulfuron, nicosulfuron, and a protoporphyrinogen oxidase inhibitor, fomesafen. Researchers have identified comparable resistant levels to ALS inhibitors in annual bluegrass populations from turfgrass systems (Cross et al. 2013; McElroy et al. 2013). Similar resistance to ALS inhibitors has been confirmed in horseweed [Conyza canadensis (L.) Cronq.], pigweeds (Amaranthus spp.), and rice barnyardgrass [Echinochloa phyllopogon (Stapf) Koso-Pol.] (Osuna et al. 2002; Whaley et al. 2006; Zheng et al. 2011).

Multiple and Cross-Resistance Experiment. Metsulfuron at $21 \mathrm{~g} \mathrm{ha}^{-1}$ injured the $S$ biotype $75 \%$ at 4 WAT but did not injure the R biotype (Table 1). Metsulfuron was more injurious to the $S$ biotype than trifloxysulfuron at $29 \mathrm{~g}^{\text {ai ha }} \mathrm{ha}^{-1}(75 \%$ vs. 45\%), but trifloxysulfuron did not injure the R biotype. Injury to the $\mathrm{R}$ biotype was equivalent to the $\mathrm{S}$ biotype from dicamba, glyphosate, and triclopyr. These herbicides averaged 39, 44, and 85\% injury, respectively. Results suggest this biotype is resistant to another sulfonylurea used for spotted spurge control in turf, trifloxysulfuron.

Turfgrass managers have limitations with alternative mechanisms of action to ALS inhibitors in warm-season grasses. For example, triclopyr is only labeled for cool-season grasses and zoysiagrass (Zoysia japonica Steud.) because of excessive injury potential from labeled use rates $\left(0.28\right.$ to $\left.1.12 \mathrm{~kg} \mathrm{ha}^{-1}\right)$ on most warm-season species during active growth (Cudney et al. 1997; McElroy and Breeden 2006). Glyphosate was less efficacious than triclopyr at rates evaluated and would be limited to spot applications for POST control of spotted spurge. Dicamba is safe on most major turfgrass species and provided equivalent control on both biotypes after 4 wk. However, dicamba was not as efficacious as triclopyr and may require tank mixtures with other herbicides for best results.

Another limitation to POST control of spotted spurge is herbicide efficacy on mature plants. In field experiments, dicamba, triclopyr, and other herbicides required greater use rates to control the $\mathrm{R}$ biotype when plants were $\sim 10 \mathrm{~cm}$ tall with multiple $(>4)$ branches, compared with seedlings treated before branching (McCullough, personal observation). Reduced control from herbicides applied to 


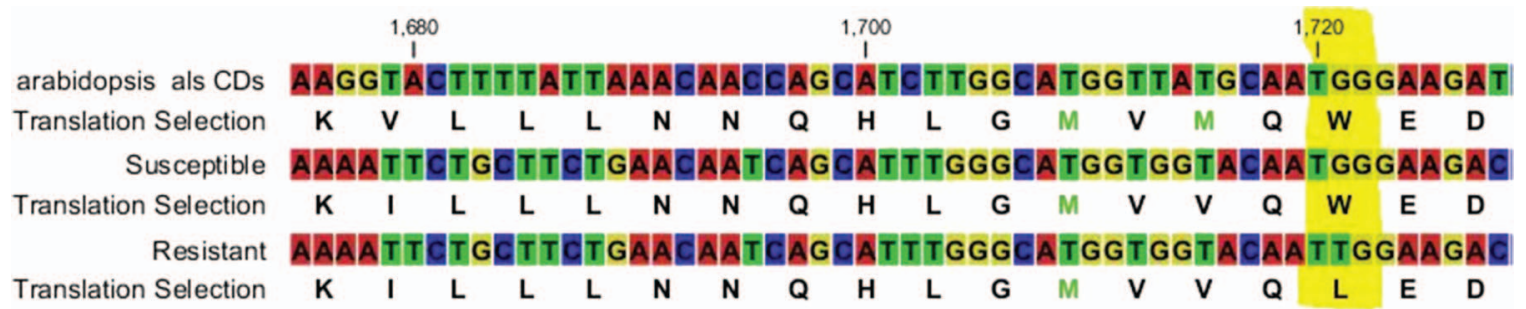

Figure 3. Alignment of acetolactate synthase (ALS) sequences flanking codon $\operatorname{Trp}_{574}$ from Arabidopsis thaliana and the spurge populations. The yellow highlight indicates the $\operatorname{Trp}_{574}$ codon in A4. thaliana. The resistant population shows a mutation (TGG to TTG) conferring $\operatorname{Trp}_{574}$ to Leu substitution in ALS enzymes. (Color for this figure is available in the online version of this article.)

mature weeds has been reported for common cocklebur (Xanthium strumarium L.), pitted morningglory (Ipomoea lacunosa L.), smooth pigweed (Amaranthus hybridus L.), and other annual weeds (Barrentine 1989; DeFelice et al. 1989; Klingman et al. 1992). Furthermore, mature weeds may have produced viable seed that could further spread resistant populations after control. Practitioners may need to modify application rates and regimens of alternative herbicides to metsulfuron for controlling mature populations of ALS-resistant spurge. Further research is needed to evaluate the efficacy of other ALS inhibitors, Photosystem II inhibitors, and organic arsenicals for controlling this biotype.

Gene Sequencing of the ALS Enzyme. The R biotype contained two amino acid substitutions: Asp-341 to Ser and Trp-574 to Leu (Figure 3; Table 2). A mutation was not detected in the Pro197 codon. Considering Asp-341 is not one of the 18 amino acid in the ALS-inhibiting herbicidebinding region and Trp-574 to Leu is historically correlated with target site resistance, it can be concluded that an amino acid substitution to Leu- 574 is the molecular mechanism of resistance for this spotted spurge biotype (McCourt et al. 2006).

Table 2. Missense mutations in the susceptible and resistant spotted spurge biotypes as revealed by nucleotide read mapping and translation to amino acid sequence.

\begin{tabular}{|c|c|c|c|c|}
\hline $\begin{array}{l}\text { Nucleotide } \\
\text { position }^{\text {a }}\end{array}$ & Reference & Polymorphism & Frequency $^{\mathrm{b}}$ & $\begin{array}{l}\text { Amino acid } \\
\text { substitution }^{c}\end{array}$ \\
\hline \multicolumn{5}{|c|}{ Susceptible spotted spurge biotype } \\
\hline 1365 & $\mathrm{~T}$ & $\mathrm{G}$ & 37.50 & $\mathrm{Leu}_{474}$ to Glu \\
\hline \multicolumn{5}{|c|}{ Resistant spotted spurge biotype } \\
\hline 1658 & G & $\mathrm{T}$ & 63.87 & $\operatorname{Trp}_{574}$ to Leu \\
\hline 959 & G & A & 45.28 & Asp $_{341}$ to Ser \\
\hline
\end{tabular}

${ }^{a}$ Nucleotide position refers to the corresponding assembly of the acetolactate synthase gene in susceptible and resistant biotypes.

${ }^{\mathrm{b}}$ Frequency is the number of mapped reads carrying the polymorphic nucleotide per the number of mapped reads carrying the reference nucleotide in the two plants evaluated.
The Trp-574 to Leu substitution has conferred resistance to sulfonylureas, imidazolinones, and pyrimidinyl-benzoic acids (McCourt et al. 2006; McElroy et al. 2013; Yu and Powles 2013). This specific mutation has been identified as the molecular basis for ALS resistance in annual bluegrass, Powell amaranth [Amaranthus powellii (S.) Wats.], kochia [Kochia scoparia (L.) Schrad.], rigid ryegrass (Lolium rigidum Gaudin), wild mustard (Sinapis arvensis L.), and other weed species (Christoffers et al. 2006; McElroy et al. 2013; Warwick et al. 2008; Yu et al. 2008; Yu and Powles 2013).

Implications from These Findings. Spotted spurge with resistance to ALS inhibitors will require alternative cultural and chemical control methods for acceptable control. Selecting alternatives to ALS inhibitors with comparable efficacy will be critical in turfgrasses susceptible to injury from other mechanisms of action, such as bermudagrass [Cynodon dactylon (L.) Pers.] or seashore paspalum. Mechanical suppression or hand weeding may be an effective approach to controlling many resistant weeds in turfgrass. However, these techniques may not be practical in large areas with severe infestations of spotted spurge.

The prolific seed production of spotted spurge will contribute to the spread of $\mathrm{R}$ biotypes. Isoxaben or other PRE herbicides should be applied before soil temperatures reach $25 \mathrm{C}$ for effective control (Asgarpour et al. 2015). The continued use of PRE herbicides throughout the summer may be necessary to control later flushes of seed germination in turfgrass. Further research is needed to determine the distribution of ALS resistance in spotted spurge and related Chamaesyce species in the United States.

This is the first report of ALS resistance in spotted spurge. This is also the first report of a herbicideresistant broadleaf weed from a turfgrass system. The confirmation of ALS resistance in a weed with substantial seed production has serious implications for herbicide resistance management. Rotating POST herbicide mechanisms of action may provide 
acceptable control in certain turfgrass species. However, alternative herbicides to ALS inhibitors may have potential for drift, turfgrass injury, or limited efficacy. The identification of new weed species with resistance to ALS inhibitors should emphasize the importance of alternative management programs, including herbicide rotation, in turfgrass and other cropping systems.

\section{Acknowledgments}

The authors thank Seth Williams from the University of Georgia for technical assistance with this research. We also thank Dr. Richard Carter from the Valdosta State University Herbarium for confirming species identification of the plants used in these experiments.

\section{Literature Cited}

Anonymous (2015) Manor herbicide label. Burr Ridge, IL: Nufarm Americas. $5 \mathrm{p}$

Asgarpour R, Ghorbani R, Khajeh-Hosseini M, Mohammadvand E, Chauhan BS (2015) Germination of spotted spurge (Chamaesyce maculata) seeds in response to different environmental factors. Weed Sci 63:502-510

Bararpour MT, Talbert RE, Frans RE (1994) Spotted spurge (Euphorbia maculata) interference with cotton (Gossypium hirsutum). Weed Sci 42:553-555

Barrentine, WL (1989) Minimum effective rate of chlorimuon and imazaqun applied to common cocklebur (Xanthium sumarium). Weed Technol 3:126-130

Brautigam A, Gowik U (2010) What can next generation sequencing do for you? Next generation sequencing as a valuable tool in plant research. Plant Biol 12:831-841

Christoffers MJ, Nandula VK, Howatt KA, Wehking TR (2006) Target-site resistance to acetolactate synthase inhibitors in wild mustard (Sinapis arvensis). Weed Sci 54:191-197

Cross GB, Skroch WA (1992) Quantification of weed seed contamination and weed development in container nurseries. J Environ Hortic 10:159-161

Cross RB, McCarty LB, Tharayil N, Whitwell T, Bridge WC (2013) Detecting annual bluegrass (Poa annua) resistance to ALS-inhibiting herbicides using a rapid diagnostic assay. Weed Sci 61:384-389

Cudney DW, Elmore CL, Gibeault VA, Reints JS (1997) Common bermudagrass (Cynodon dactylon) management in coolseason turfgrass. Weed Technol 11:478-483

DeFelice, MS, Brown WB, Aldrich RJ, Sims BD, Judy DT, Guetble DR (1989) Weed control in soybeans (Glycine max) with reduced rates of postemergence herbicides. Weed Sci 37:365-374

Derr J (1994) Weed control in container-grown herbaceous perennials. HortScience 29:95-97

Derr J (2002) Tolerance of ornamental grasses to preemergence herbicides. J Environ Hortic 20:161-165

Derr JF (2012) Broadleaf weed control with sulfonylurea herbicides in cool-season turfgrass. Weed Technol 26:582-586
Dunn PH (1979) The distribution of leaf spurge (Euphorbia esula) and other weed Euphorbia spp. in the United States. Weed Sci 27:509-515

Elmore CD, McDaniel S (1986) Identification and distribution of the weedy spruges in the Delta of Mississippi. Weed Sci 34:911-915

Grabherr MG, Haas BJ, Yassour M, Levin JZ (2011) Full-length transcriptome assembly from RNA-seq data without a reference genome. Nat Biotechnol 29:644-652

Haas BJ, Papanicolaou A, Yassour M, Grabnerr M (2013) De novo transcript sequence reconstruction from RNA-seq using the Trinity platform for reference generation and analysis. Nat Protoc 8:1494-1512

Heap I (2015) The International Survey of Herbicide Resistant Weeds. http://www.weedscience.org. Accessed August 8, 2015

Hope JH (1982) Biology, Control and Spotted Spurge (Euphorbia maculata L.) in Soybean. Ph.D dissertation. Knoxville, TN: University of Tennessee. $67 \mathrm{p}$

Judge CA, Neal JC, Weber JB (2004) Dose and concentration responses of common nursery weeds to Gallery, Surflan, and Treflan. J Environ Hortic 22:106-112

Klingman TE, King CA, Oliver LR (1992) Effect of application rate, weed species, and weed stage of growth on imazethapyr activity. Weed Sci 40:227-232

Krochmal A (1952) Seeds of weedy Euphorbia species and their identification. Weeds 1:243-255

McCarty, LB (1991) Metsulfuron for prostrate spurge control in bermudagrass. Proc South Weed Sci Soc 44:180.

McCourt JA, Pang SS, King-Scott J, Guddat LW, and Duggleby RG (2006) Herbicide-binding sites revealed in the structure of plant acetohydroxyacid synthase. Proc Natl Acad Sci USA 103:569-573

McCullough PE, Yu J, McElroy JS, Chen S, Zhang H, Grey TL, Czarnota MA (2015) ALS-resistant annual sedge (Cyperus compressus) confirmed in turfgrass. Weed Sci 64:33-41.

McElroy JS, Breeden GK (2006) Triclopyr safens the use of fluazifop and fenoxaprop on zoysiagrass while maintaining bermudagrass suppression. Appl Turfgrass Sci. DOI: 10.1094/ ATS-2006-0502-01-RS

McElroy JS, Flessner ML, Wang Z, Dane F, Walker RH, Wehtje GR (2013) A Trp574 to Leu amino acid substitution in the ALS gene of annual bluegrass (Poa annua) is associated with resistance to ALS-inhibiting herbicides. Weed Sci 61: $21-25$

Norcini JG, Aldrich JH (1992) Spotted spurge control and phytotoxicity to daylily from preemergence herbicides. J Environ Hortic 10:14-17

Osuna MD, Vidotto F, Fischer AJ, Bayer DE, De Prado R, Ferrero A (2002) Cross resistance to bispyribac-sodium and bensulfuron-methyl in Echinochloa phyllopogon and Cyperus difformis. Pestic Biochem Physiol 73:9-17

Powles SB, Yu Q (2010) Evolution in action: plants resistant to herbicides. Annu Rev Plant Biol 61:317-347

Shaner DL (1999) Resistance to acetolactate synthase (ALS) inhibitors in the United States: history, occurrence, detection, and management. J Weed Sci Technol 44:405-411

Tranel PJ, Wright TR (2002) Resistance of weeds to ALSinhibiting herbicides: what have we learned. Weed Sci 50: 700-712

Trezzi MM, Felippi CL, Mattei D, Silva HL, Nunes AL, Debastiani C, Vidal RA, Maques A (2005) Mulitple reistance to acetolactate synthase and protoprphyrinogen oxidase inhibitors in 
Euphorbia heterophylla bioytpes. J Environ Sci Health Part B Pestic Food Contam Agric Wastes 40:101-109

Warwick Si, Xu R, Sauder C, Beckie HJ (2008) Acetolactate synthase target-site mutations and single nucleotide polymorphism genotyping in ALS-resistant kochia (Kochia scoparia). Weed Sci 56:797-806

Whaley CM, Wilson HP, Westwood JH (2006) ALS resistance in several smooth pigweed biotypes. Weed Sci 54: 828-832

Yu Q, Heping H, Powles SB (2008) Mutations of the ALS gene endowing resistance to ALS-inhibiting herbicides in Lolium rigidum populations. Pest Manag Sci 64:1229-1236
Yu Q, Powles SB (2014) Resistance to AHAS inhibitor herbicides: current understanding. Pest Manag Sci 70:1340-1350

Zheng DM, Kruger GR, Singh S, Davis VM, Tranel PJ, Weller SC, Johnson WG (2011) Cross-resistance of horseweed (Conyza canadensis) populations with three different ALS mutations. Pest Manag Sci 67:1486-1492

Received August 21, 2015, and approved November 11, 2015.

Associate Editor for this paper: Steven Seefeldt, University of Alaska at Fairbanks. 